\title{
Proposal for a body balance training program for children through an integrative literature review
}

\author{
Marta de Vargas Romero ${ }^{1}$ \\ https://orcid.org/0000-0002-1780-932X \\ Helena Bolli Mota ${ }^{1}$ \\ https://orcid.org/0000-0001-9505-0964 \\ Letícia Arruda Nóro' \\ https://orcid.org/0000-0002-4410-5184 \\ Valdete Alves Valentins dos Santos Filha ${ }^{1}$ \\ https://orcid.org/0000-0002-9397-5039
}

Universidade Federal de Santa Maria UFSM, Santa Maria, Rio Grande do Sul, Brasil.

Conflict of interests: Nonexistent

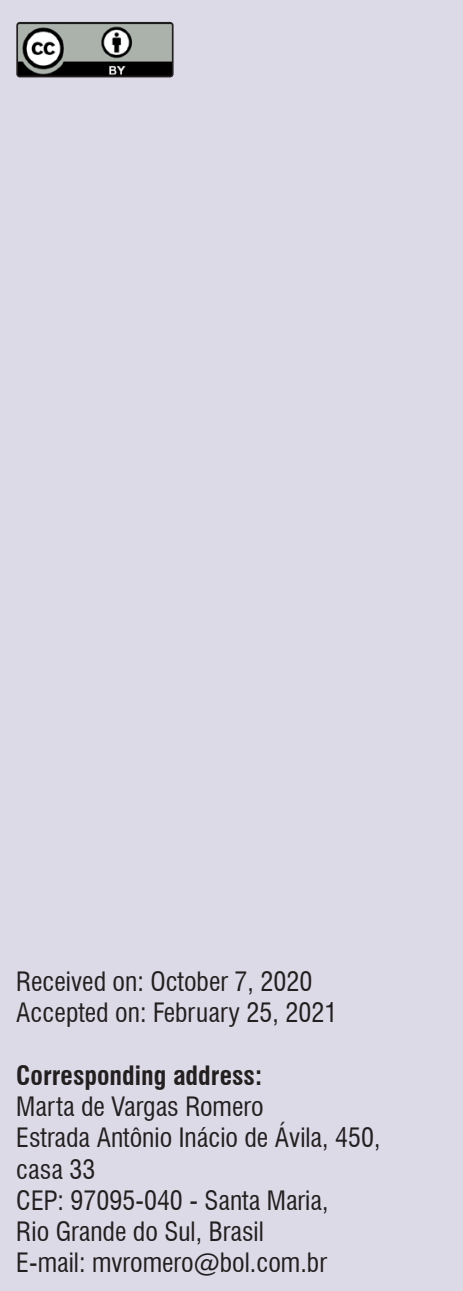

\section{ABSTRACT}

Objective: to verify, in the literature, the proposals to rehabilitate the vestibular function, so as to propose a training program for body balance for children.

Methods: this article sought studies that proposed to rehabilitate or train body balance in the Medical Literature Analysis and Retrieval System Online (MEDLINE/PubMed) and Scientific Electronic Library Online (SCIELO) databases, in addition to digital sources from Brazilian public universities. As descriptors, the terms "rehabilitation", "balance" and "child" were used, combined with the Boolean operator AND. The variables analyzed were: public submitted to the intervention, number of subjects and age group, number and frequency of sessions, number and/or time of execution of the exercise, duration of the session and the program.

Results: 17 (60.74\%) articles were Brazilian, 14 (50\%) used the Cawthorne and Cooksey protocol, 9 (32.14\%) studied children, and the majority (67.85\%) organized the program in weeks. A body balance training program, stimulating the three body balance systems, consisting of 30-minute sessions twice a week for 7 weeks, totaling 14 sessions, was developed.

Conclusion: the analysis of the variable related to the protocol/strategy to rehabilitate the vestibular function indicated that no study proposed the stimulation of the three body balance systems, with no standardization for children, adults and the elderly. A vestibular function rehabilitation program was developed for children, with stimulation of these three systems, expanding the therapeutic possibilities in this area.

Keywords: Postural Balance; Rehabilitation; Child 


\section{INTRODUCTION}

Body balance is a complex sensorimotor phenomenon generated by the integration of information from three sensory systems (visual, proprioceptive and vestibular) and processed in the Central Nervous System ${ }^{1}$.

Changes in maintaining body balance can cause symptoms such as tinnitus and hearing loss ${ }^{2}$. Pediatric vestibular disorders are of great importance in the course of child development, as they can have a series of repercussions, such as delayed motor development and learning, potentially interfering with language, speech, writing and reading ${ }^{3}$.

In addition to identifying schoolchildren at risk for otoneurological disorders, and thus minimizing their effects on child development and academic performance, it is urgent to prepare teachers to recognize these complaints in their students. Moreover, parents should be instructed to take their child through a complete otoneurological assessment in the event of complaints of this nature ${ }^{4}$.

In the search to remedy or alleviate symptoms related to changes in the vestibular system, researchers sought alternatives for their treatment. There are several forms of treatment for vestibular disorders, especially drugs, surgeries, nutritional guidance, correction of inappropriate habits, psychotherapy and vestibular rehabilitation (VR) .

National ${ }^{6,7}$ and international-13 studies have proposed rehabilitating children from VR, with some proving that this treatment is effective and safe for children ${ }^{8,9}$.

The objective of this study was to verify, in the scientific publications, the proposals to rehabilitate the vestibular function, and based on the data from the integrative review, to propose a body balance training program for children.

\section{METHODS}

This is an integrative review, of a documental character, whose research took place in the period from March to September 2018.

The first stage was the selection of studies that dealt with VR. The survey was carried out on the Medical Literature Analysis and Retrieval System Online (MEDLINE/PubMed) and Scientific Electronic Library Online (SCIELO) databases, in addition to the virtual sources of public institutions of Higher Education: Federal University of Santa Maria (UFSM), Federal
University of São Paulo (USP) and Federal University of Rio Grande do Sul (UFRGS). A total of 3743 studies were obtained, which were repeated in more than one base of papers.

National and international material was searched by combining the following descriptors in English (DeCS), without restriction of period, language or nationality, using the Boolean operator "AND":

1. Rehabilitation AND vestibular;

2. Balance AND rehabilitation;

3. Rehabilitation AND vestibular AND child.

The inclusion criteria for selecting the material were:

a) Full text;

b) Free access;

c) To present a therapeutic program or strategy to rehabilitate or train vestibular function (unpublished, adapted or replicated).

After the analysis of the studies, those who did not adhere to the theme of that study or who were repeated in more than one database were excluded. Academic works and texts that were not available in full were also excluded. Thus, a total of 28 studies met the inclusion criteria and were used in this study.

The following analysis variables were considered:

a) Public submitted to the intervention, including the number of subjects and age group;

b) Number and frequency of intervention sessions;

c) Number/time of repetitions of the exercise and/or duration of the session;

d) Total duration of the program.

The data were analyzed descriptively by means of percentage, which were presented by means of Chart.

The second stage of this study was the elaboration of the BB training program aimed at children. For the elaboration, the following were determined: frequency of sessions, duration and/or number of repetition of the activity, session time and period of application of the protocol.

The following domains were determined: activity to be performed, focus (BB system prioritized in that activity specifically), duration and/or number of repetition and material to be used.

\section{LITERATURE REVIEW}

Chart 1 shows the selected studies. This Chart includes the authors and country in which was developed, the protocol or rehabilitation strategy or vestibular training used, the audience studied, the number of sessions performed by the researcher and the frequency, the number of repetitions of the 
exercises, the duration of the session and the therapeutic program.

As shown in Chart 1, it was found that 17 of the selected studies (60.74\%) were carried out in Brazil, with the predominant use of the Cawthorne and Cooksey protocol $(50 \%)$, both in isolated form $(32.15 \%)$, as associated with other strategies (17.85\%).

Regarding to the public studied, the results indicated that nine $(32.14 \%)$ of the studies investigated the child/ adolescent public, which is also the target public of the present study, and the others $(67.86 \%)$ dealt with the adult and/or elderly public.

Analyzing the studies presented in Chart 1, the number of sessions showed important variability, starting from a single session (7.14\%) to 112 sessions (3.57\%), predominantly studies that proposed a variable number of sessions (14.28\%). Just a study (3.57\%) that did not specify the number of sessions.

As well as the number of sessions scheduled, the frequency of these therapeutic sessions was also variable, ranging from single session $(7.14 \%)$, through biweekly and monthly (7.14\%) to daily (3.57\%). Two studies $(7.14 \%)$ did not specify the frequency of the session. Finally, the periodicity prevalent among the selected studies was two weekly sessions, with nine (32.14\%) studies adopting this conduct.

Among the studies dedicated to children present in Chart 1 , one study $(11.11 \%)$ stood out that indicated that the exercises were repeated 10 times, while two studies $(22.22 \%)$ indicated the time between one and three minutes per exercise. Finally, one study (11.11\%) indicated both the number of repetitions (three to 10) and the duration (one to two minutes).

Concerning the duration of the session, among the studies in Chart 1 with children's samples, only three (33.33\%) indicated in their methodologies the duration of the session, with estimates varying from 20 to 60 minutes, with an average among the three studies of 41 minutes.

From the detailed analysis of the results in Chart 1 , the training program presented in Chart 2 was elaborated. The activity, focus and number of repetitions or execution time were presented, and finally the material used.

Chart 1. Studies selected from a bibliographic survey that proposed to rehabilitate or train vestibular function

\begin{tabular}{|c|c|c|c|c|c|c|c|}
\hline $\begin{array}{l}\text { Authors } \\
\text { Country }\end{array}$ & $\begin{array}{l}\text { Protocol } \\
\text { Strategy }\end{array}$ & $\begin{array}{l}\text { Audience and } \\
\text { Age group } \\
\text { (in years) }\end{array}$ & Sessions & Periodicity & $\begin{array}{l}\text { Repetition } \\
\text { exercise }\end{array}$ & $\begin{array}{l}\text { Duration } \\
\text { Session }\end{array}$ & $\begin{array}{l}\text { Duration } \\
\text { Program }\end{array}$ \\
\hline $\begin{array}{c}\text { Bittar et al. } \\
(2002) \\
\text { Brazil }^{6}\end{array}$ & $\begin{array}{l}\text { Cawthorne } \\
\text { and Cooksey }\end{array}$ & $\begin{array}{l}24 \text { children } \\
4 \text { to } 15\end{array}$ & 4 & $\begin{array}{l}\text { 1st day } \\
\text { 15th day } \\
\text { 30th day } \\
60 \text { th day }\end{array}$ & 10 & No & $\begin{array}{c}8 \\
\text { weeks }\end{array}$ \\
\hline $\begin{array}{c}\text { Medeiros et al. } \\
(2003) \\
\text { Brazil }^{7}\end{array}$ & $\begin{array}{l}\text { Cawthorne } \\
\text { and Cooksey }\end{array}$ & $\begin{array}{l}10 \text { children } \\
5 \text { to } 10\end{array}$ & 4 & $\begin{array}{l}\text { 1st day } \\
15 \text { th day } \\
30 \text { th day } \\
60 \text { th day }\end{array}$ & No & No & $\begin{array}{c}8 \\
\text { weeks }\end{array}$ \\
\hline $\begin{array}{l}\text { Nishino et al. } \\
(2005) \\
\text { Brazil }^{21}\end{array}$ & $\begin{array}{l}\text { Personalized vestibular rehabilitation } \\
\text { (including Cawthorne and Cooksey) }\end{array}$ & $\begin{array}{c}37 \\
\text { adults } \\
21 \text { to } 87\end{array}$ & $\begin{array}{l}1 \\
\text { to } 15\end{array}$ & Once a week & No & No & No \\
\hline $\begin{array}{c}\text { Ribeiro and } \\
\text { Pereira (2005) } \\
\text { Brazi|23 } \\
\end{array}$ & $\begin{array}{l}\text { Cawthorne } \\
\text { and Cooksey }\end{array}$ & $\begin{array}{l}15 \text { elderly } \\
60 \text { to } 69\end{array}$ & 27 & 3 times a week & $\begin{array}{l}\text { From } 4 \text { seconds } \\
\text { to } 2 \text { minutes }\end{array}$ & $\begin{array}{c}60 \\
\text { minutes }\end{array}$ & $\begin{array}{c}9 \\
\text { weeks }\end{array}$ \\
\hline $\begin{array}{l}\text { Zanardini et al. } \\
(2007) \\
\text { Brazi }\left.\right|^{28}\end{array}$ & $\begin{array}{l}\text { Cawthorne } \\
\text { and Cooksey }\end{array}$ & $\begin{array}{l}8 \text { elderly } \\
63 \text { to } 82\end{array}$ & 112 & Twice a week & No & No & $\begin{array}{c}8 \\
\text { weeks }\end{array}$ \\
\hline $\begin{array}{l}\text { Mantello et al. } \\
(2008) \\
\text { Brazil }^{18}\end{array}$ & $\begin{array}{l}\text { Cawthorne } \\
\text { and Cooksey }\end{array}$ & $\begin{array}{l}40 \text { elderly } \\
60 \text { a } 84\end{array}$ & $\begin{array}{l}4 \\
\text { to } 8\end{array}$ & Biweekly & No & No & No \\
\hline $\begin{array}{l}\text { Patatas et al. } \\
(2009) \\
\text { Brazil }^{22}\end{array}$ & $\begin{array}{l}\text { Personalized vestibular rehabilitation } \\
\text { (based on Cawthorne and Cooksey, } \\
\text { Herdman, Davis and O'Leary ) }\end{array}$ & $\begin{array}{l}22 \text { adults } \\
16 \text { to } 87\end{array}$ & Variable & Once a week & No & No & $\begin{array}{l}\text { Minimum } 6 \\
\text { weeks }\end{array}$ \\
\hline $\begin{array}{l}\text { Rogatto et al. } \\
(2010) \\
\text { Brazil26 }^{26}\end{array}$ & $\begin{array}{l}\text { Association between sensory integration } \\
\text { therapy with protocol of Cawthorne and } \\
\text { Cooksey }\end{array}$ & $\begin{array}{l}1 \text { adult } \\
47\end{array}$ & 10 & Twice a week & 10 & $\begin{array}{c}30 \\
\text { minutes }\end{array}$ & $\begin{array}{c}10 \\
\text { weeks }\end{array}$ \\
\hline $\begin{array}{l}\text { Mirelman et al. } \\
(2011) \\
\text { Israel }^{31}\end{array}$ & $\begin{array}{c}\text { Activities for posture, static and dynamic } \\
\text { balance through audio-bio-feedback (ABF } \\
\text { System) }\end{array}$ & $\begin{array}{l}7 \text { adults } \\
59 \text { to } 85\end{array}$ & 18 & 3 times a week & No & $\begin{array}{l}45 \\
\text { minutes }\end{array}$ & $\begin{array}{c}6 \\
\text { weeks }\end{array}$ \\
\hline
\end{tabular}




\begin{tabular}{|c|c|c|c|c|c|c|c|}
\hline $\begin{array}{l}\text { Authors } \\
\text { Country }\end{array}$ & $\begin{array}{l}\text { Protocol } \\
\text { Strategy }\end{array}$ & $\begin{array}{l}\text { Audience and } \\
\text { Age group } \\
\text { (in years) }\end{array}$ & Sessions & Periodicity & $\begin{array}{l}\text { Repetition } \\
\text { exercise }\end{array}$ & $\begin{array}{l}\text { Duration } \\
\text { Session }\end{array}$ & $\begin{array}{l}\text { Duration } \\
\text { Program }\end{array}$ \\
\hline $\begin{array}{l}\text { Morezetti et al. } \\
\quad(2011) \\
\text { Brazil| }^{20}\end{array}$ & $\begin{array}{l}\text { Exercises de Davis \& O 'Leary (1994) } \\
\text { and } \\
\text { UNIFESP standardized vestibular } \\
\text { rehabilitation protocol }\end{array}$ & $\begin{array}{l}20 \text { adults } 33 \\
\text { to } 88\end{array}$ & 8 & Once a week & 10 & $\begin{array}{l}10 \text { a } 45 \\
\text { minutes }\end{array}$ & No \\
\hline $\begin{array}{c}\text { Martini (2012) } \\
\text { Brazil|19 }^{19} \\
\end{array}$ & $\begin{array}{l}\text { Virtual reality strategy using Wii Fit } \circledast \mathrm{da} \\
\text { Nintendo }\end{array}$ & $\begin{array}{l}7 \text { adults } \\
55 \text { to } 75 \\
\end{array}$ & 10 & Twice a week & 3 to 6 & No & $\begin{array}{c}5 \\
\text { weeks }\end{array}$ \\
\hline $\begin{array}{l}\text { Ricci (2013) } \\
\text { Brazil| }^{24}\end{array}$ & $\begin{array}{l}\text { Cawthorne e Cooksey (conventional) and } \\
\text { Cawthorne e Cooksey (modified) }\end{array}$ & $\begin{array}{l}82 \text { elderly } \\
\text { equal or over } \\
65\end{array}$ & 16 & Twice a week & No & $\begin{array}{c}50 \\
\text { minutes }\end{array}$ & $\begin{array}{c}8 \\
\text { weeks }\end{array}$ \\
\hline $\begin{array}{l}\text { Garcia et al. } \\
(2013) \\
\text { Brazil }^{14}\end{array}$ & $\begin{array}{c}\text { Vestibular rehabilitation through Balance } \\
\text { Rehabilitation Unit (BRU) (experimental } \\
\text { group) }\end{array}$ & $\begin{array}{l}44 \text { adults } \\
18 \text { to } 60\end{array}$ & 12 & Twice a week & No & No & $\begin{array}{c}6 \\
\text { weeks }\end{array}$ \\
\hline $\begin{array}{l}\text { Marioni et al. } \\
\quad(2013) \\
\text { Italy }^{37}\end{array}$ & $\begin{array}{l}\text { Isolated exercises protocol and combined } \\
\text { exercise protocol (vestibular rehabilitation } \\
\text { assisted by computerized posturography }\end{array}$ & $\begin{array}{l}28 \text { elderly } \\
\text { mean } 74\end{array}$ & 6 & Once a week & $\begin{array}{c}1 \text { minute (isolated } \\
\text { exercises) } \\
\text { and } 2 \text { minutes } \\
\text { (with support of } \\
\text { posturography) } \\
\end{array}$ & $\begin{array}{c}30 \\
\text { minutes }\end{array}$ & $\begin{array}{c}6 \\
\text { weeks }\end{array}$ \\
\hline $\begin{array}{l}\text { Alahmari et al. } \\
\qquad(2014) \\
\text { USA }^{36}\end{array}$ & $\begin{array}{l}\text { Personalized protocol (control) } \\
\text { and protocol based on virtual reality }\end{array}$ & $\begin{array}{l}38 \text { adults } \\
27 \text { to } 78\end{array}$ & 6 & Once a week & $\begin{array}{c}4 \\
\text { minutes }\end{array}$ & $\begin{array}{l}45 \text { a } 60 \\
\text { minutes }\end{array}$ & $\begin{array}{c}6 \\
\text { weeks }\end{array}$ \\
\hline $\begin{array}{l}\text { Leong et al. } \\
\text { (2014) } \\
\text { USA }^{8}\end{array}$ & $\begin{array}{c}\text { Saccadic training through The King-Devick } \\
\text { Remediation Software }\end{array}$ & $\begin{array}{l}76 \text { children } \\
\text { mean } 6,58\end{array}$ & 18 & 3 times a week & No & $\begin{array}{c}20 \\
\text { minutes }\end{array}$ & $\begin{array}{c}6 \\
\text { weeks }\end{array}$ \\
\hline $\begin{array}{l}\text { Rocha Junior } \\
\text { et al. }(2014) \\
\text { Brazil| }\end{array}$ & $\begin{array}{l}\text { VertiG0 protocol! (based on Cawthorne and } \\
\text { Cooksey) }\end{array}$ & $\begin{array}{c}9 \text { elderly } \\
\text { equal or } \\
\text { over } \\
60 \\
\end{array}$ & 30 & Twice a week & 30 to 50 & $\begin{array}{c}50 \\
\text { minutes }\end{array}$ & $\begin{array}{c}12 \\
\text { weeks }\end{array}$ \\
\hline $\begin{array}{c}\text { Macedo } \\
(2014) \\
\text { Brazil }^{16}\end{array}$ & Cawthorne and Cooksey & $\begin{array}{l}36 \text { elderly } \\
65 \text { to } 70\end{array}$ & Variable & Twice a week & No & $\begin{array}{c}50 \\
\text { minutes }\end{array}$ & $\begin{array}{l}\text { Minimum } \\
12 \text { and } \\
\text { maximum } \\
16 \text { weeks }\end{array}$ \\
\hline $\begin{array}{l}\text { Goulème et al. } \\
\text { (2015) } \\
\text { France }^{9}\end{array}$ & Estrategy Multitest Equilibre from Framiral & $\begin{array}{l}32 \text { children } \\
\text { Mean } 9,9\end{array}$ & 1 & Single & $\begin{array}{l}\text { Single } \\
3 \text { minutes }\end{array}$ & $\begin{array}{c}3 \\
\text { minutes }\end{array}$ & 1 day \\
\hline $\begin{array}{l}\text { McCoy et al. } \\
(2015) \\
\text { USA }^{30}\end{array}$ & $\begin{array}{c}\text { Sensorimotor } \\
\text { Training to Affect Balance, Engagement } \\
\text { and Learning (STABEL) system } \\
\text { (virtual reality) }\end{array}$ & $\begin{array}{l}22 \text { children } \\
8 \text { to } 16\end{array}$ & 1 & Single & $\begin{array}{l}3 \text { blocks } \\
6 \text { minutes }\end{array}$ & No & 1 day \\
\hline $\begin{array}{l}\text { Tsukamoto et } \\
\text { al. }(2015) \\
\text { Brazil }^{27}\end{array}$ & $\begin{array}{c}\text { Personalized protocol } \\
\text { - Manual cervical therapy } \\
\text {-Exercises for shoulder girdle } \\
\text {-Cawthorne and Cooksey } \\
\text {-Proprioceptive and balance training }\end{array}$ & $\begin{array}{l}20 \text { adults } \\
20 \text { to } 80\end{array}$ & 12 & Once a week & No & $\begin{array}{c}60 \\
\text { minutes }\end{array}$ & $\begin{array}{c}12 \\
\text { weeks }\end{array}$ \\
\hline $\begin{array}{l}\text { Ozgen et al. } \\
(2016) \\
\text { Turkey }^{38}\end{array}$ & Personalized protocol designed for the study & $\begin{array}{l}40 \text { adults } \\
22 \text { to } 60\end{array}$ & 8 & Once a week & $\begin{array}{l}\text { Approximately } 1 \\
\text { minute }\end{array}$ & $\begin{array}{l}30 \text { to } 45 \\
\text { minutes }\end{array}$ & $\begin{array}{c}8 \\
\text { weeks }\end{array}$ \\
\hline $\begin{array}{l}\text { Fong et al. } \\
\quad(2016) \\
\text { Hong Kong }\end{array}$ & $\begin{array}{l}\text { Protocol based on Movement Assessment } \\
\text { Battery for Children Manual - MABC) }\end{array}$ & $\begin{array}{l}88 \text { children } \\
\text { mean } 7,9\end{array}$ & 24 & Twice a week & 5 to 10 minutes & No & $\begin{array}{c}12 \\
\text { weeks }\end{array}$ \\
\hline $\begin{array}{l}\text { Lofti et al. } \\
(2016) \\
\operatorname{Iran}^{11}\end{array}$ & Ppediatric balance therapy - PTB & $\begin{array}{l}\text { Children } \\
4 \text { to } 12\end{array}$ & No & No & $\begin{array}{l}8 \text { to } 10 \text { repetitions } \\
\text { (1 to } 2 \text { minutes) }\end{array}$ & No & $\begin{array}{l}\text { Variable } \\
4 \text { to } \\
10 \text { weeks }\end{array}$ \\
\hline $\begin{array}{l}\text { Manso et al. } \\
(2016) \\
\text { Brazili }\end{array}$ & $\begin{array}{c}\text { Cawthorne e Cooksey } \\
\text { (control group) and ocular fixation stimulus } \\
\text { protocol (experimental group) }\end{array}$ & $\begin{array}{l}40 \text { adults } \\
23 \text { to } 63\end{array}$ & 12 & Twice a week & 1 to 3 minutes & $\begin{array}{c}40 \\
\text { minutes }\end{array}$ & $\begin{array}{c}6 \\
\text { weeks }\end{array}$ \\
\hline $\begin{array}{l}\text { Jafarlou et al. } \\
(2017) \\
\operatorname{Iran}^{12}\end{array}$ & $\begin{array}{l}\text { Protocol based on oculomotor tests of } \\
\text { vectoelectronystagmography }\end{array}$ & $\begin{array}{l}50 \text { children } \\
8 \text { to } 12\end{array}$ & 16 & Twice a week & No & $\begin{array}{c}60 \\
\text { minutes }\end{array}$ & $\begin{array}{c}8 \\
\text { weeks }\end{array}$ \\
\hline $\begin{array}{l}\text { Ebrahimi et al. } \\
\qquad \begin{array}{c}(2017) \\
\operatorname{Iran}^{13}\end{array}\end{array}$ & Own protocol & $\begin{array}{l}24 \text { children } \\
7 \text { to } 12\end{array}$ & 24 & 3 times a week & 1 a 2 minutes & $\begin{array}{c}45 \\
\text { minutes }\end{array}$ & $\begin{array}{c}8 \\
\text { weeks }\end{array}$ \\
\hline $\begin{array}{l}\text { Longo et a. } \\
(2018) \\
\text { Brazil }^{15}\end{array}$ & Cawthorne and Cooksey & $\begin{array}{l}13 \text { adults } \\
42 \text { to } 65\end{array}$ & 8 & No & No & $\begin{array}{c}20 \\
\text { minutes }\end{array}$ & No \\
\hline
\end{tabular}

Captions: UNIFESP: Federal University of São Paulo, USA: United States of America. 
The results indicated that most studies (67.85\%) proposed therapeutic programs organized in weeks, with an average of eight weeks. Still, it was found that four studies (14.28\%) did not specify the time required by the therapeutic program, while two studies (10.52\%) indicated a single therapeutic session.

Chart 2. Body balance training program with the proposed activity, the main focus of each activity, time/repetition and material used

\begin{tabular}{|c|c|c|c|}
\hline \multicolumn{4}{|c|}{ DAY 1} \\
\hline Activity & Focus & Time/repetition & Material \\
\hline $\begin{array}{l}\text { To keep feet apart (approximately } 10 \mathrm{~cm} \text { between feet) on a } \\
\text { stable base with open eyes directed at a fixed point on the wall. }\end{array}$ & $\begin{array}{c}\text { Vestibular } \\
\text { Somatosensory } \\
\text { Visual }\end{array}$ & $\begin{array}{l}1 \text { minute } \\
\text { Repeat } 3 \text { times }\end{array}$ & \\
\hline $\begin{array}{l}\text { To keep feet apart on a stable base (approximately } 10 \mathrm{~cm} \\
\text { between feet) with closed eyes. }\end{array}$ & $\begin{array}{c}\text { Vestibular } \\
\text { Somatosensory }\end{array}$ & $\begin{array}{c}1 \text { minute } \\
\text { Repeat } 3 \text { times }\end{array}$ & $\longrightarrow$ \\
\hline $\begin{array}{l}\text { To keep feet together on a stable base with open eyes directed } \\
\text { at a fixed point on the wall. }\end{array}$ & $\begin{array}{c}\text { Vestibular } \\
\text { Somatosensory } \\
\text { Visual }\end{array}$ & $\begin{array}{l}1 \text { minute } \\
\text { Repeat } 3 \text { times }\end{array}$ & \\
\hline To keep feet together on a stable base with closed eyes. & $\begin{array}{c}\text { Vestibular } \\
\text { Somatosensory }\end{array}$ & $\begin{array}{c}1 \text { minute } \\
\text { Repeat } 3 \text { times }\end{array}$ & $\longrightarrow$ \\
\hline $\begin{array}{l}\text { To walk in a straight line between } 2 \text { tapes with } 20 \mathrm{~cm} \text { between } \\
\text { them and } 5 \mathrm{~m} \text { long (in the first free attempt, being able to look } \\
\text { at the floor, and in the next ones looking at a fixed point on the } \\
\text { wall).* }\end{array}$ & $\begin{array}{l}\text { Vestibular } \\
\text { Visual }\end{array}$ & To take the round trip 3 times & Blue adhesive tape \\
\hline $\begin{array}{l}\text { To walk in a straight line between } 2 \text { tapes with } 20 \mathrm{~cm} \text { between } \\
\text { them and } 5 \mathrm{~m} \text { long with closed eyes * }\end{array}$ & Vestibular & To take the round trip 3 times & Blue adhesive tape \\
\hline $\begin{array}{l}\text { To look to the right without visual stimulation (only eyes move, } \\
\text { the head remains immobile). Stay in position for } 10 \text { seconds. } \\
\text { Return to the Center. }\end{array}$ & Visual & Repeat 3 times & \\
\hline $\begin{array}{l}\text { To look to the left without visual stimulation (only eyes move, } \\
\text { the head remains immobile). Stay in position for } 10 \text { seconds. } \\
\text { Return to the Center. }\end{array}$ & Visual & Repeat 3 times & \\
\hline $\begin{array}{l}\text { To look up without visual stimulation (only eyes move, the head } \\
\text { remains immobile). Stay in position for } 10 \text { seconds. Return to } \\
\text { the center. }\end{array}$ & Visual & Repeat 3 times & \\
\hline $\begin{array}{l}\text { To look down without visual stimulation (only eyes move, the } \\
\text { head remains immobile). Stay in position for } 10 \text { seconds. } \\
\text { Return to the center. }\end{array}$ & Visual & Repeat 3 times & \\
\hline Play: imitation of animals (in group). & $\begin{array}{l}\text { To reinforce trained movements } \\
\text { and postures }\end{array}$ & $\begin{array}{l}\text { Each child was given the } \\
\text { figure of } 1 \text { animal to imitate. } \\
\text { Colleagues should guess. }\end{array}$ & $\begin{array}{l}\text { Animal figures: } \\
\text { Frog, bird, horse, snake, lion, } \\
\text { alligator, kangaroo } \\
\end{array}$ \\
\hline \multicolumn{4}{|c|}{ DAY 2} \\
\hline Activity & Focus & Time/repetition & Material \\
\hline $\begin{array}{l}\text { To keep feet together on a stable base with open eyes directed } \\
\text { at a fixed point on the wall. }\end{array}$ & $\begin{array}{c}\text { Vestibular } \\
\text { Somatossensory } \\
\text { Visual } \\
\end{array}$ & $\begin{array}{l}1 \text { minute } \\
\text { Repetition } 3 \text { times }\end{array}$ & \\
\hline To keep feet together on a stable base with closed eyes. & $\begin{array}{c}\text { Vestibular } \\
\text { Somatosensory }\end{array}$ & $\begin{array}{c}1 \text { minute } \\
\text { Repetition } 3 \text { times }\end{array}$ & \\
\hline $\begin{array}{l}\text { To place the right foot in front of the left on a stable base } \\
\text { looking at a fixed point on the wall. }\end{array}$ & $\begin{array}{c}\text { Vestibular } \\
\text { Somatosensory } \\
\text { Visual }\end{array}$ & $\begin{array}{l}1 \text { minute } \\
\text { Repetition } 3 \text { times }\end{array}$ & \\
\hline $\begin{array}{l}\text { To place the left foot in front of the right on a stable base } \\
\text { looking at a fixed point on the wall. }\end{array}$ & $\begin{array}{c}\text { Vestibular } \\
\text { Somatosensory } \\
\text { Visual }\end{array}$ & $\begin{array}{l}1 \text { minute } \\
\text { Repetition } 3 \text { times }\end{array}$ & \\
\hline $\begin{array}{l}\text { To place the right foot in front of the left on a stable base with } \\
\text { closed eyes. }\end{array}$ & $\begin{array}{c}\text { Vestibular } \\
\text { Somatosensory }\end{array}$ & $\begin{array}{c}1 \text { minute } \\
\text { Repetition } 3 \text { times }\end{array}$ & \\
\hline $\begin{array}{l}\text { To place the left foot in front of the right on a stable base with } \\
\text { closed eyes. }\end{array}$ & $\begin{array}{c}\text { Vestibular } \\
\text { Somatosensory }\end{array}$ & $\begin{array}{c}1 \text { minute } \\
\text { Repetition } 3 \text { times }\end{array}$ & - \\
\hline $\begin{array}{l}\text { To walk in a straight line between } 2 \text { tapes with } 15 \mathrm{~cm} \text { between } \\
\text { both and } 5 \mathrm{~m} \text { long (in the first free attempt, being able to look } \\
\text { at the floor, and in the next ones looking at a fixed point on the } \\
\text { wall). * }\end{array}$ & $\begin{array}{l}\text { Vestibular } \\
\text { Visual }\end{array}$ & To take the round trip 3 times & Blue adhesive tape \\
\hline
\end{tabular}




\begin{tabular}{|c|c|c|c|}
\hline $\begin{array}{l}\text { To walk in a straight line between } 2 \text { tapes with } 15 \mathrm{~cm} \text { between } \\
\text { both and } 5 \mathrm{~m} \text { long with closed eyes. }{ }^{*}\end{array}$ & $\begin{array}{c}\text { Vestibular } \\
\text { Somatosensory }\end{array}$ & To take the round trip 3 times & Blue adhesive tape \\
\hline $\begin{array}{l}\text { To follow object movement (ball) slowly to the right and to } \\
\text { the left (movement of the eyes only). Stay in position for } 10 \\
\text { seconds and return to the center, moving to the other side. * }\end{array}$ & Visual & To repeat 3 times (round trip) & Toy bowling ball (black) \\
\hline $\begin{array}{l}\text { To follow up and down object movement (ball) (up and down) } \\
\text { (only eyes move, the head remains immobile). Stay in the } \\
\text { position for } 10 \text { seconds and returns to the center, moving to the } \\
\text { other position. * }\end{array}$ & Visual & Repeat 3 times & Toy bowling ball (black) \\
\hline Play: to play with large ball (in group). & $\begin{array}{l}\text { Reinforce trained movements } \\
\text { and postures }\end{array}$ & $\begin{array}{l}\text { 1. Sitting in a circle, play ball } \\
\text { with your hands at random for } \\
\text { your colleague. } \\
\text { 2. Standing, kicking, throw the } \\
\text { ball at random to colleagues. } \\
\text { 3. Standing, throw the ball with } \\
\text { your hands at your colleagues, } \\
\text { randomly. }\end{array}$ & Volleyball \\
\hline \multicolumn{4}{|c|}{ DAY 3} \\
\hline Activity & Focus & Time/repetition & Material \\
\hline $\begin{array}{l}\text { To place your right foot in front of the left side on the stable } \\
\text { base looking at the fixed point on the wall. }\end{array}$ & $\begin{array}{l}\text { Vestibular } \\
\text { Somatosensory } \\
\text { Visual }\end{array}$ & $\begin{array}{l}1 \text { minute } \\
\text { Repeat } 3 \text { times }\end{array}$ & \\
\hline $\begin{array}{l}\text { To place the left foot in front of the right on a stable base } \\
\text { looking at a fixed point on the wall. }\end{array}$ & $\begin{array}{l}\text { Vestibular } \\
\text { Somatosensory } \\
\text { Visual }\end{array}$ & $\begin{array}{l}1 \text { minute } \\
\text { Repeat } 3 \text { times }\end{array}$ & \\
\hline $\begin{array}{l}\text { To place the right foot in front of the left on a stable base with } \\
\text { closed eyes. }\end{array}$ & $\begin{array}{c}\text { Vestibular } \\
\text { Somatosensory }\end{array}$ & $\begin{array}{c}1 \text { minute } \\
\text { Repeat } 3 \text { times }\end{array}$ & \\
\hline $\begin{array}{l}\text { To place the left foot in front of the right on a stable base with } \\
\text { closed eyes. }\end{array}$ & $\begin{array}{c}\text { Vestibular } \\
\text { Somatosensory }\end{array}$ & $\begin{array}{c}1 \text { minute } \\
\text { Repeat } 3 \text { times }\end{array}$ & $\longrightarrow$ \\
\hline $\begin{array}{l}\text { To stand on a stable and elevated base with both feet supported } \\
\text { with open eyes looking at a fixed point on the wall. * }\end{array}$ & $\begin{array}{c}\text { Vestibular } \\
\text { Somatosensory } \\
\text { Visual }\end{array}$ & $\begin{array}{l}1 \text { minute } \\
\text { Repeat } 3 \text { times }\end{array}$ & $\begin{array}{l}\text { Wooden bench height } 22 \mathrm{~cm} \\
\text { and seat with a diameter of } \\
24 \mathrm{~cm}\end{array}$ \\
\hline $\begin{array}{l}\text { To stand on a stable and elevated base with both feet supported } \\
\text { with closed eyes. * }\end{array}$ & $\begin{array}{l}\text { Vestibular } \\
\text { Somatosensory }\end{array}$ & $\begin{array}{l}1 \text { minute } \\
\text { Repeat } 3 \text { times }\end{array}$ & $\begin{array}{l}\text { Wooden bench height } 22 \mathrm{~cm} \\
\text { and seat with a diameter of } \\
24 \mathrm{~cm}\end{array}$ \\
\hline $\begin{array}{l}\text { To walk in a straight line between } 2 \text { tapes with } 10 \mathrm{~cm} \text { between } \\
\text { the tapes and } 5 \mathrm{~m} \text { long (in the first free attempt, being able to } \\
\text { look at the floor, and in the next ones looking at a fixed point on } \\
\text { the wall). * }\end{array}$ & $\begin{array}{l}\text { Vestibular } \\
\text { Somatosensory } \\
\text { Visual }\end{array}$ & Repeat 3 times round trip & $\begin{array}{l}\text { Adhesive tape in blue color } \\
\text { (very prominent white floor) }\end{array}$ \\
\hline $\begin{array}{l}\text { To walk in a straight line between } 2 \text { tapes with } 10 \mathrm{~cm} \text { between } \\
\text { tapes and } 5 \mathrm{~m} \text { long with closed eyes. * }\end{array}$ & $\begin{array}{c}\text { Vestibular } \\
\text { Somatosensory }\end{array}$ & Repeat 3 times round trip & $\begin{array}{l}\text { Adhesive tape in blue color } \\
\text { (very prominent white floor) }\end{array}$ \\
\hline $\begin{array}{l}\text { To follow object movement (ball) in a circular direction } \\
\text { (clockwise) only with eye movement, head remains immobile. } \\
\star\end{array}$ & Visual & Repeat 3 complete spins & Toy bowling ball (black) \\
\hline $\begin{array}{l}\text { To follow object movement (ball) in a circular direction } \\
\text { (counterclockwise) with eye movement only, head remains } \\
\text { immobile. * }\end{array}$ & Visual & Repeat 3 complete spins & Toy bowling ball (black) \\
\hline Play: play with small ball (in group) & $\begin{array}{l}\text { Train movements used in the } \\
\text { session }\end{array}$ & $\begin{array}{l}\text { 1. Sitting in a circle, play ball } \\
\text { with your hands at random for } \\
\text { your colleague; } \\
\text { 2. Standing, kicking, throw the } \\
\text { ball at random to colleagues. } \\
\text { 3. Standing, throw the ball with } \\
\text { your hands at your colleagues, } \\
\text { randomly. }\end{array}$ & Tennis ball \\
\hline \multicolumn{4}{|c|}{ DAY 4} \\
\hline Activity & Focus & Time/repetition & Material \\
\hline $\begin{array}{l}\text { To stand on a stable and elevated base with both feet supported } \\
\text { with open eyes looking at a fixed point on the wall. * }\end{array}$ & $\begin{array}{l}\text { Vestibular } \\
\text { Somatosensory } \\
\text { Visual }\end{array}$ & $\begin{array}{l}1 \text { minute } \\
\text { Repeat } 3 \text { times }\end{array}$ & $\begin{array}{l}\text { Wooden bench height } 22 \mathrm{~cm} \\
\text { and seat with a diameter of } \\
24 \mathrm{~cm}\end{array}$ \\
\hline $\begin{array}{l}\text { To stand on a stable and elevated base with both feet supported } \\
\text { with closed eyes. * }\end{array}$ & $\begin{array}{c}\text { Vestibular } \\
\text { Somatosensory }\end{array}$ & $\begin{array}{l}1 \text { minute } \\
\text { Repeat } 3 \text { times }\end{array}$ & $\begin{array}{l}\text { Wooden bench height } 22 \mathrm{~cm} \\
\text { and seat with a diameter of } \\
24 \mathrm{~cm}\end{array}$ \\
\hline
\end{tabular}




\begin{tabular}{|c|c|c|c|}
\hline $\begin{array}{l}\text { To stand with your right foot supported on a stable base, with } \\
\text { your left leg bent (foot off the ground), with open eyes looking } \\
\text { at a fixed point on the wall. }\end{array}$ & $\begin{array}{l}\text { Vestibular } \\
\text { Somatosensory } \\
\text { Visual }\end{array}$ & $\begin{array}{l}1 \text { minute } \\
\text { Repeat } 3 \text { times }\end{array}$ & \\
\hline $\begin{array}{l}\text { To stand with your left foot supported on a stable base, with } \\
\text { your leg bent (foot off the ground), with open eyes looking at a } \\
\text { fixed point on the wall. }\end{array}$ & $\begin{array}{l}\text { Vestibular } \\
\text { Somatosensory } \\
\text { Visual }\end{array}$ & $\begin{array}{l}1 \text { minute } \\
\text { Repeat } 3 \text { times }\end{array}$ & \\
\hline $\begin{array}{l}\text { To stand with your right foot supported on a stable base, with } \\
\text { your left leg bent (foot off the floor), with closed eyes. }\end{array}$ & $\begin{array}{c}\text { Vestibular } \\
\text { Somatosensory }\end{array}$ & $\begin{array}{c}1 \text { minute } \\
\text { Repeat } 3 \text { times }\end{array}$ & \\
\hline $\begin{array}{l}\text { To stand with left foot supported on a stable base, with leg bent } \\
\text { (foot off the ground), with closed eyes. }\end{array}$ & $\begin{array}{c}\text { Vestibular } \\
\text { Somatosensory }\end{array}$ & $\begin{array}{c}1 \text { minute } \\
\text { Repeat } 3 \text { times }\end{array}$ & \\
\hline $\begin{array}{l}\text { To walk straight on tape for } 5 \mathrm{~m} \text { in length (in the first free } \\
\text { attempt, being able to look at the floor, and in the next ones } \\
\text { looking at a fixed point on the wall). * }\end{array}$ & $\begin{array}{c}\text { Vestibular } \\
\text { Somatosensory } \\
\text { Visual }\end{array}$ & Repeat 3 times round trip & Blue adhesive tape \\
\hline To walk straight on tape for $5 \mathrm{~m}$ with closed eyes. * & $\begin{array}{c}\text { Vestibular } \\
\text { Somatosensory }\end{array}$ & Repeat 5 times round trip & Blue adhesive tape \\
\hline $\begin{array}{l}\text { To follow object movement (ball) in a circular direction } \\
\text { (clockwise) only with eye movement, head remains } \\
\text { immobile. * }\end{array}$ & Visual & Repeat 5 complete spins & Toy bowling ball (black) \\
\hline $\begin{array}{l}\text { To follow the movement of the object (ball) in a circular } \\
\text { direction (counterclockwise) with only the movement of the } \\
\text { eyes, the head remains immobile. * }\end{array}$ & Visual & Repeat 5 complete spins & Toy bowling ball (black) \\
\hline Play: hopscotch (individual). * & $\begin{array}{l}\text { Reinforce trained movements } \\
\text { and postures }\end{array}$ & Each player played 5 times & $\begin{array}{l}\text { Chalk } \\
\text { Stone }\end{array}$ \\
\hline \multicolumn{4}{|c|}{ DAY 5} \\
\hline Activity & Focus & Time/repetition & Material \\
\hline $\begin{array}{l}\text { To stand on a stable and elevated base with your right foot } \\
\text { supported and your left foot elevated (in the air), with eyes } \\
\text { open looking at a fixed point on the wall. * }\end{array}$ & $\begin{array}{c}\text { Vestibular } \\
\text { Somatosensory } \\
\text { Visual }\end{array}$ & $\begin{array}{l}1 \text { minute } \\
\text { Repeat } 3 \text { times }\end{array}$ & $\begin{array}{l}\text { Wooden bench height } 22 \mathrm{~cm} \\
\text { and seat with a diameter of } \\
24 \mathrm{~cm}\end{array}$ \\
\hline $\begin{array}{l}\text { To stand on a stable and elevated base with your left foot } \\
\text { supported and your right foot high (in the air), with open eyes } \\
\text { looking at a fixed point on the wall. * }\end{array}$ & $\begin{array}{c}\text { Vestibular } \\
\text { Somatosensory } \\
\text { Visual }\end{array}$ & $\begin{array}{c}1 \text { minute } \\
\text { Repeat } 3 \text { times }\end{array}$ & $\begin{array}{l}\text { Wooden bench height } 22 \mathrm{~cm} \\
\text { and seat with a diameter of } \\
\qquad 24 \mathrm{~cm}\end{array}$ \\
\hline $\begin{array}{l}\text { To keep feet apart (approximately } 10 \mathrm{~cm} \text { between feet) on an } \\
\text { unstable base with open eyes directed at a fixed point on the } \\
\text { wall. ** }\end{array}$ & $\begin{array}{l}\text { Vestibular } \\
\text { Somatosensory } \\
\text { Visual }\end{array}$ & $\begin{array}{c}1 \text { minute } \\
\text { Repeat } 3 \text { times }\end{array}$ & $\begin{array}{l}\text { Silicone cushion (measuring } 40 \\
\qquad \mathrm{~cm} \times 50 \mathrm{~cm})\end{array}$ \\
\hline $\begin{array}{l}\text { To keep feet apart (approximately } 10 \mathrm{~cm} \text { between feet) on an } \\
\text { unstable base with closed eyes. }{ }^{* *}\end{array}$ & $\begin{array}{c}\text { Vestibular } \\
\text { Somatosensory }\end{array}$ & $\begin{array}{c}1 \text { minute } \\
\text { Repeat } 3 \text { times }\end{array}$ & $\begin{array}{l}\text { Silicone cushion (measuring } 40 \\
\mathrm{~cm} \times 50 \mathrm{~cm})\end{array}$ \\
\hline $\begin{array}{l}\text { To jump with feet together on } 5 \mathrm{~m} \text { long tape (first try you can } \\
\text { look at the floor, on the others to look at the fixed point on the } \\
\text { wall). * }\end{array}$ & $\begin{array}{c}\text { Vestibular } \\
\text { Somatosensory } \\
\text { Visual }\end{array}$ & Repeat 3 times round trip Ita & $\begin{array}{l}\text { Adhesive tape in blue color } \\
\text { (very prominent white floor) }\end{array}$ \\
\hline $\begin{array}{l}\text { To follow with the eyes (child's eye height) the approach and } \\
\text { removal of object (ball). }{ }^{*}\end{array}$ & Visual & Repeat 3 times round trip & Toy bowling ball (black) \\
\hline Play: hopscotch (individual) * & $\begin{array}{l}\text { Reinforce trained movements } \\
\text { and postures }\end{array}$ & Each player played 5 times & $\begin{array}{l}\text { Chalk } \\
\text { Stone }\end{array}$ \\
\hline \multicolumn{4}{|c|}{ DAY 6} \\
\hline Activity & Focus & Time/repetition & Material \\
\hline $\begin{array}{l}\text { To keep feet apart (approximately } 10 \mathrm{~cm} \text { between feet) on an } \\
\text { unstable base with open eyes directed at a fixed point on the } \\
\text { wall. ** }\end{array}$ & $\begin{array}{c}\text { Vestibular } \\
\text { Somatosensory } \\
\text { Visual }\end{array}$ & $\begin{array}{c}1 \text { minute } \\
\text { Repeat } 3 \text { times }\end{array}$ & $\begin{array}{l}\text { Silicone cushion (measuring } 40 \\
\qquad \mathrm{~cm} \times 50 \mathrm{~cm})\end{array}$ \\
\hline $\begin{array}{l}\text { To keep feet apart (approximately } 10 \mathrm{~cm} \text { between feet) on an } \\
\text { unstable base with closed eyes. }{ }^{*}\end{array}$ & $\begin{array}{c}\text { Vestibular } \\
\text { Somatosensory }\end{array}$ & $\begin{array}{c}1 \text { minute } \\
\text { Repeat } 3 \text { times }\end{array}$ & $\begin{array}{l}\text { Silicone cushion (measuring } 40 \\
\mathrm{~cm} \times 50 \mathrm{~cm})\end{array}$ \\
\hline $\begin{array}{l}\text { To keep feet together on an unstable base with open eyes } \\
\text { directed at a fixed point on the wall. ** }\end{array}$ & $\begin{array}{c}\text { Vestibular } \\
\text { Somatosensory } \\
\text { Visual } \\
\end{array}$ & $\begin{array}{l}1 \text { minute } \\
\text { Repeat } 3 \text { times }\end{array}$ & $\begin{array}{l}\text { Silicone cushion (measuring } 40 \\
\qquad \mathrm{~cm} \times 50 \mathrm{~cm})\end{array}$ \\
\hline To keep feet together on an unstable base with closed eyes. ** & $\begin{array}{c}\text { Vestibular } \\
\text { Somatosensory }\end{array}$ & $\begin{array}{c}1 \text { minute } \\
\text { Repeat } 3 \text { times }\end{array}$ & $\begin{array}{l}\text { Silicone cushion (measuring } 40 \\
\mathrm{~cm} \times 50 \mathrm{~cm})\end{array}$ \\
\hline $\begin{array}{l}\text { To jump over } 5 \mathrm{~m} \text { long tape with your right foot, go back with } \\
\text { your left foot (first try you can look at the floor, the others try to } \\
\text { look at the fixed point on the wall). * }\end{array}$ & $\begin{array}{c}\text { Vestibular } \\
\text { Somatosensory } \\
\text { Visual }\end{array}$ & Repeat 3 times & $\begin{array}{l}\text { Adhesive tape in blue color } \\
\text { (very prominent white floor) }\end{array}$ \\
\hline
\end{tabular}




\begin{tabular}{|c|c|c|c|}
\hline $\begin{array}{l}\text { On a stable base, look for a luminous point (laser) in the } 4 \\
\text { cardinal points projected on the wall (only with the eyes, the } \\
\text { head remains immobile). Order of presentation: right, left, top, } \\
\text { bottom, left, right, bottom, top. }\end{array}$ & Visual & Repeat the script 3 times & Laser \\
\hline Play: bowling game & $\begin{array}{l}\text { Reinforce trained movements } \\
\text { and postures }\end{array}$ & $\begin{array}{l}\text { Each throw tossed the ball } 5 \\
\text { times }\end{array}$ & Bowling game \\
\hline \multicolumn{4}{|c|}{ DAY 7} \\
\hline Activity & Focus & Time/repetition & Material \\
\hline $\begin{array}{l}\text { To keep feet together on an unstable base with open eyes } \\
\text { directed at a fixed point on the wall. ** }\end{array}$ & $\begin{array}{c}\text { Vestibular } \\
\text { Somatosensory } \\
\text { Visual }\end{array}$ & $\begin{array}{l}1 \text { minute } \\
\text { Repeat } 3 \text { times }\end{array}$ & $\begin{array}{l}\text { Silicone cushion (measuring } 40 \\
\qquad \mathrm{~cm} \times 50 \mathrm{~cm})\end{array}$ \\
\hline To keep feet together on an unstable base with closed eyes. ** & $\begin{array}{c}\text { Vestibular } \\
\text { Somatosensory }\end{array}$ & $\begin{array}{c}1 \text { minute } \\
\text { Repeat } 3 \text { times }\end{array}$ & $\begin{array}{l}\text { Silicone cushion (measuring } 40 \\
\qquad \mathrm{~cm} \times 50 \mathrm{~cm})\end{array}$ \\
\hline $\begin{array}{l}\text { To keep your right foot in front of your left on an unstable base } \\
\text { with your open eyes looking at a fixed point on the wall. ** }\end{array}$ & $\begin{array}{c}\text { Vestibular } \\
\text { Somatosensory } \\
\text { Visual } \\
\end{array}$ & $\begin{array}{l}1 \text { minute } \\
\text { Repeat } 3 \text { times }\end{array}$ & $\begin{array}{l}\text { Silicone cushion (measuring } 40 \\
\qquad \mathrm{~cm} \times 50 \mathrm{~cm})\end{array}$ \\
\hline $\begin{array}{l}\text { To keep your left foot in front of your left on an unstable base } \\
\text { with open eyes looking at a fixed point on the wall. ** }\end{array}$ & $\begin{array}{c}\text { Vestibular } \\
\text { Somatosensory } \\
\text { Visual }\end{array}$ & $\begin{array}{l}1 \text { minute } \\
\text { Repeat } 3 \text { times }\end{array}$ & $\begin{array}{l}\text { Silicone cushion (measuring } 40 \\
\qquad \mathrm{~cm} \times 50 \mathrm{~cm})\end{array}$ \\
\hline $\begin{array}{l}\text { To keep right foot in front of the left on an unstable base with } \\
\text { closed eyes. ** }\end{array}$ & $\begin{array}{c}\text { Vestibular } \\
\text { Somatosensory }\end{array}$ & $\begin{array}{c}1 \text { minute } \\
\text { Repeat } 3 \text { times }\end{array}$ & $\begin{array}{l}\text { Silicone cushion (measuring } 40 \\
\qquad \mathrm{~cm} \times 50 \mathrm{~cm})\end{array}$ \\
\hline $\begin{array}{l}\text { To keep left foot in front of the left on an unstable base with } \\
\text { closed eyes. ** }\end{array}$ & $\begin{array}{c}\text { Vestibular } \\
\text { Somatossensorial } \\
\end{array}$ & $\begin{array}{c}1 \text { minute } \\
\text { Repeat } 3 \text { times }\end{array}$ & $\begin{array}{l}\text { Silicone cushion (measuring } 40 \\
\mathrm{~cm} \times 50 \mathrm{~cm})\end{array}$ \\
\hline $\begin{array}{l}\text { To keep your eyes fixed on an object (ball) and turn your head } \\
\text { towards NO. }\end{array}$ & $\begin{array}{l}\text { Vestibular } \\
\text { Visual }\end{array}$ & $\begin{array}{l}\text { Repeat } 3 \text { complete round-trip } \\
\text { times }\end{array}$ & Toy bowling ball (black) \\
\hline To keep staring at object (ball) and turn your head towards YES. & $\begin{array}{l}\text { Vestibular } \\
\text { Visual }\end{array}$ & $\begin{array}{l}\text { Repeat } 3 \text { complete round-trip } \\
\text { times }\end{array}$ & Toy bowling ball (black) \\
\hline Play: bowling game (darts) * & $\begin{array}{l}\text { Reinforce trained movements } \\
\text { and postures }\end{array}$ & $\begin{array}{l}\text { Each throw tossed the ball } 5 \\
\text { times }\end{array}$ & Target shooting game (darts) \\
\hline \multicolumn{4}{|c|}{ DAY 8} \\
\hline Activity & Focus & Time/repetition & Material \\
\hline $\begin{array}{l}\text { To stand on the unstable base, vertically stable, again on the } \\
\text { unstable base, keeping your open eyes directed to a fixed point } \\
\text { on the wall. ** }\end{array}$ & $\begin{array}{l}\text { Vestibular } \\
\text { Somatosensory } \\
\text { Visual }\end{array}$ & $\begin{array}{l}\text { Repeat } 3 \text { times complete (exit } \\
\text { and return to trampoline) }\end{array}$ & $\begin{array}{l}\text { Silicone cushion (measuring } 40 \\
\qquad \mathrm{~cm} \times 50 \mathrm{~cm})\end{array}$ \\
\hline $\begin{array}{l}\text { To stand on the unstable base, jump on the stable, jump back } \\
\text { to the unstable base with your closed eyes. }{ }^{* *}\end{array}$ & $\begin{array}{c}\text { Vestibular } \\
\text { Somatosensory }\end{array}$ & $\begin{array}{l}\text { Repeat } 3 \text { times complete (exit } \\
\text { and return to trampoline) }\end{array}$ & $\begin{array}{l}\text { Silicone pad (measuring } 40 \mathrm{~cm} \\
\text { x 50 cm) }\end{array}$ \\
\hline $\begin{array}{l}\text { To sit on an unstable and elevated base and move your body } \\
\text { (feel the elasticity) with your eyes open. * }\end{array}$ & $\begin{array}{c}\text { Vestibular } \\
\text { Somatosensory } \\
\text { Visual } \\
\end{array}$ & Stay 1 minute & Trampoline (jump) \\
\hline $\begin{array}{l}\text { To sit on an unstable and elevated base and move your body } \\
\text { (feel the elasticity) with your closed eyes. * }\end{array}$ & $\begin{array}{c}\text { Vestibular } \\
\text { Somatosensory }\end{array}$ & Stay 1 minute & Trampoline (jump) \\
\hline $\begin{array}{l}\text { Standing on the stable base, rotate the body } 90^{\circ} \text { clockwise. Do } \\
4 \text { consecutive spins, completing } 360^{\circ} \text {. Keep your eyes open. }\end{array}$ & $\begin{array}{c}\text { Vestibular } \\
\text { SomatosensoryVisual }\end{array}$ & $\begin{array}{l}\text { Complete } 3 \text { complete spins } \\
\text { (respecting individual limits) }\end{array}$ & \\
\hline $\begin{array}{l}\text { To keep your eyes fixed on an object (ball) and turn your head } \\
\text { in the direction of MAYBE. }\end{array}$ & $\begin{array}{l}\text { Vestibular } \\
\text { Visual }\end{array}$ & $\begin{array}{l}\text { Repeat } 3 \text { complete round-trip } \\
\text { times }\end{array}$ & Toy bowling ball (black) \\
\hline Play: target shooting (darts) * & $\begin{array}{l}\text { Reinforce trained movements } \\
\text { and postures } \\
\end{array}$ & $\begin{array}{l}\text { Each throw tossed the ball } 5 \\
\text { times }\end{array}$ & Target shooting game (darts) \\
\hline \multicolumn{4}{|c|}{ DAY 9} \\
\hline Activity & Focus & Time/repetition & Material \\
\hline $\begin{array}{l}\text { To sit on an unstable and elevated base and move your body } \\
\text { (feel the elasticity) with open eyes * }\end{array}$ & $\begin{array}{l}\text { Vestibular } \\
\text { Somatosensory } \\
\text { Visual }\end{array}$ & Stay 1 minute & Trampoline (jump) \\
\hline $\begin{array}{l}\text { To sit on an unstable and elevated base and move your body } \\
\text { (feel the elasticity) with your closed eyes * }\end{array}$ & $\begin{array}{c}\text { Vestibular } \\
\text { Somatosensory }\end{array}$ & Stay 1 minute & Trampoline (jump) \\
\hline $\begin{array}{l}\text { Standing with feet apart on an unstable and elevated base with } \\
\text { eyes open looking at a fixed point on the wall. ** }\end{array}$ & $\begin{array}{c}\text { Vestibular } \\
\text { Somatosensory } \\
\text { Visual }\end{array}$ & $\begin{array}{l}1 \text { minute } \\
\text { Repeat } 3 \text { times }\end{array}$ & Trampoline (jump) \\
\hline $\begin{array}{l}\text { Stand with feet apart on an unstable and elevated base with } \\
\text { closed eyes. ** }\end{array}$ & $\begin{array}{c}\text { Vestibular } \\
\text { Somatosensory }\end{array}$ & $\begin{array}{c}1 \text { minute } \\
\text { Repeat } 3 \text { times }\end{array}$ & Trampoline (jump) \\
\hline
\end{tabular}




\begin{tabular}{|c|c|c|c|}
\hline $\begin{array}{l}\text { To follow with eyes (head remains immobile) movement of } \\
\text { moving point on the wall (laser) horizontally (child's eye height) } \\
\text { unstable and elevated base with closed eyes. ** }\end{array}$ & Visual & $\begin{array}{l}\text { Repeat } 3 \text { times complete (round } \\
\text { trip) }\end{array}$ & Laser \\
\hline $\begin{array}{l}\text { To follow with the eyes (head remains immobile) movement of } \\
\text { a moving point on the wall (laser) vertically. }\end{array}$ & Visual & $\begin{array}{l}\text { Repeat } 3 \text { times complete (round } \\
\text { trip) }\end{array}$ & Laser \\
\hline Play: target shooting (darts) * & $\begin{array}{l}\text { Reinforce trained movements } \\
\text { and postures }\end{array}$ & $\begin{array}{c}\text { Each player threw the ball } 5 \\
\text { times }\end{array}$ & Target shooting game (darts) \\
\hline \multicolumn{4}{|c|}{ DAY 10} \\
\hline Activity & Focus & Time/repetition & Material \\
\hline $\begin{array}{l}\text { Stand with your feet apart on the unstable and elevated base } \\
\text { (with your open eyes looking at the fixed point on the wall). ** }\end{array}$ & $\begin{array}{c}\text { Vestibular } \\
\text { Somatosensory } \\
\text { Visual }\end{array}$ & $\begin{array}{l}1 \text { minute } \\
\text { Repeat } 3 \text { times }\end{array}$ & $\begin{array}{l}\text { Trampoline } \\
\text { (jump) }\end{array}$ \\
\hline $\begin{array}{l}\text { Stand with feet apart on an unstable and elevated base with } \\
\text { closed eyes. ** }\end{array}$ & $\begin{array}{c}\text { Vestibular } \\
\text { Somatosensory }\end{array}$ & $\begin{array}{c}1 \text { minute } \\
\text { Repeat } 3 \text { times }\end{array}$ & $\begin{array}{l}\text { Trampoline } \\
\text { (jump) }\end{array}$ \\
\hline $\begin{array}{l}\text { Stand with your feet together on an unstable, elevated base, } \\
\text { with your open eyes, staring at the wall. ** }\end{array}$ & $\begin{array}{c}\text { Vestibular } \\
\text { Somatosensory } \\
\text { Visual }\end{array}$ & $\begin{array}{l}1 \text { minute } \\
\text { Repeat } 3 \text { times }\end{array}$ & $\begin{array}{l}\text { Trampoline } \\
\text { (jump) }\end{array}$ \\
\hline $\begin{array}{l}\text { Stand with feet together on an unstable and elevated base with } \\
\text { closed eyes. ** }\end{array}$ & $\begin{array}{c}\text { Vestibular } \\
\text { Somatosensory }\end{array}$ & $\begin{array}{c}1 \text { minute } \\
\text { Repeat } 3 \text { times }\end{array}$ & $\begin{array}{l}\text { Trampoline } \\
\text { (jump) }\end{array}$ \\
\hline $\begin{array}{l}\text { To follow with the eyes (the head remains immobile) the } \\
\text { movement of a moving point on the wall (laser) in the } 8 \\
\text { inverted (horizontal) position in a clockwise direction. }\end{array}$ & Visual & 3 repetitions & Laser \\
\hline $\begin{array}{l}\text { To follow with the eyes (head remains immovable) the } \\
\text { movement of a moving point on the wall (laser) in the } 8 \\
\text { inverted (horizontal) position in a counterclockwise direction. }\end{array}$ & Visual & 3 repetitions & Laser \\
\hline Play: my boss asked & $\begin{array}{l}\text { Reinforce trained movements } \\
\text { and postures }\end{array}$ & $\begin{array}{l}\text { Each child was the boss } 1 \text { time } \\
\text { and the trainer } 1 \text { time. }\end{array}$ & - \\
\hline \multicolumn{4}{|c|}{ DAY 11} \\
\hline Activity & Focus & Time/repetition & Material \\
\hline $\begin{array}{l}\text { To stand with feet together on an unstable and elevated base } \\
\text { with open eyes, looking fixedly on the wall. ** }\end{array}$ & $\begin{array}{c}\text { Vestibular } \\
\text { Somatosensory } \\
\text { Visual }\end{array}$ & $\begin{array}{l}1 \text { minute } \\
\text { Repeat } 3 \text { times }\end{array}$ & $\begin{array}{l}\text { Trampoline } \\
\text { (jump) }\end{array}$ \\
\hline $\begin{array}{l}\text { To stand with feet together on an unstable and elevated base } \\
\text { with closed eyes. ** }\end{array}$ & $\begin{array}{c}\text { Vestibular } \\
\text { Somatosensory }\end{array}$ & $\begin{array}{l}1 \text { minute } \\
\text { Repeat } 3 \text { times }\end{array}$ & $\begin{array}{l}\text { Trampoline } \\
\text { (jump) }\end{array}$ \\
\hline $\begin{array}{l}\text { To jump on an unstable and elevated base with open eyes } \\
\text { looking at a fixed point on the wall. ** }\end{array}$ & $\begin{array}{c}\text { Vestibular } \\
\text { Somatosensory } \\
\text { Visual }\end{array}$ & $\begin{array}{c}\text { Jump } 60 \text { times divided into } 3 \\
\text { parts }\end{array}$ & $\begin{array}{l}\text { Trampoline } \\
\text { (jump) }\end{array}$ \\
\hline $\begin{array}{l}\text { To jump on an unstable and elevated base (trampoline - jump) } \\
\text { with closed eyes. ** }\end{array}$ & $\begin{array}{l}\text { Vestibular } \\
\text { Somatosensory }\end{array}$ & $\begin{array}{l}\text { Jump } 60 \text { times divided into } 3 \\
\text { parts ( } 20 \text { times each) }\end{array}$ & $\begin{array}{l}\text { Trampoline } \\
\text { (jump) }\end{array}$ \\
\hline $\begin{array}{l}\text { To stand with a right foot on an unstable and elevated base with } \\
\text { open eyes looking at a fixed point on the wall. ** }\end{array}$ & $\begin{array}{c}\text { Vestibular } \\
\text { Somatosensory } \\
\text { Visual }\end{array}$ & $\begin{array}{l}1 \text { minute } \\
\text { Repeat } 3 \text { times }\end{array}$ & $\begin{array}{l}\text { Trampoline } \\
\text { (jump) }\end{array}$ \\
\hline $\begin{array}{l}\text { To stand with right foot on an unstable and elevated base with } \\
\text { open eyes looking at a fixed point on the wall. ** }\end{array}$ & $\begin{array}{c}\text { Vestibular } \\
\text { Somatosensory } \\
\text { Visual }\end{array}$ & $\begin{array}{l}1 \text { minute } \\
\text { Repeat } 3 \text { times }\end{array}$ & $\begin{array}{l}\text { Trampoline } \\
\text { (jump) }\end{array}$ \\
\hline $\begin{array}{l}\text { On an unstable base keep your eyes fixed on an object (ball) } \\
\text { and turn your head in the direction of NO ** }\end{array}$ & $\begin{array}{c}\text { Vestibular } \\
\text { Somatosensory } \\
\text { Visual }\end{array}$ & $\begin{array}{l}\text { Repeat } 3 \text { complete round-trip } \\
\text { times }\end{array}$ & $\begin{array}{l}\text { Toy bowling ball (black) } \\
\text { Silicone cushion }\end{array}$ \\
\hline $\begin{array}{l}\text { On an unstable base, keep your eyes fixed on an object (ball) } \\
\text { and turn your head in the direction of YES ** }\end{array}$ & $\begin{array}{c}\text { Vestibular } \\
\text { Somatosensory } \\
\text { Visual }\end{array}$ & $\begin{array}{l}\text { Repeat } 3 \text { complete round-trip } \\
\text { times }\end{array}$ & Toy bowling ball (black) \\
\hline Play: jump rope & $\begin{array}{l}\text { Reinforce trained movements } \\
\text { and postures }\end{array}$ & Free time & Rope \\
\hline \multicolumn{4}{|c|}{ DAY 12} \\
\hline Activity & Focus & Time/repetition & Material \\
\hline $\begin{array}{l}\text { To jump on an unstable and elevated base with open eyes } \\
\text { looking at a fixed point on the wall. ** }\end{array}$ & $\begin{array}{c}\text { Vestibular } \\
\text { Somatosensory } \\
\text { Visual }\end{array}$ & $\begin{array}{l}\text { Jump } 60 \text { times divided into } 3 \\
\text { parts (20 times each) }\end{array}$ & $\begin{array}{l}\text { Trampoline } \\
\text { (jump) }\end{array}$ \\
\hline
\end{tabular}




\begin{tabular}{|c|c|c|c|}
\hline To jump on an unstable and elevated base with closed eyes. ** & $\begin{array}{c}\text { Vestibular } \\
\text { Somatosensory }\end{array}$ & $\begin{array}{l}\text { Jump } 60 \text { times divided into } 3 \\
\text { parts (20 times each) }\end{array}$ & $\begin{array}{c}\text { Trampoline } \\
\text { (jump) }\end{array}$ \\
\hline $\begin{array}{l}\text { To stand with the right foot on an unstable and elevated base } \\
\text { with open eyes looking at a fixed point on the wall. ** }\end{array}$ & $\begin{array}{l}\text { Vestibular } \\
\text { Somatosensory } \\
\text { Visual }\end{array}$ & $\begin{array}{l}1 \text { minute } \\
\text { Repeat } 3 \text { times }\end{array}$ & $\begin{array}{l}\text { Trampoline } \\
\text { (jump) }\end{array}$ \\
\hline $\begin{array}{l}\text { To stand with the right foot on an unstable and elevated base } \\
\text { with open eyes looking at a fixed point on the wall. ** }\end{array}$ & $\begin{array}{l}\text { Vestibular } \\
\text { Somatosensory } \\
\text { Visual }\end{array}$ & $\begin{array}{l}1 \text { minute } \\
\text { Repeat } 3 \text { times }\end{array}$ & $\begin{array}{l}\text { Trampoline } \\
\text { (jump) }\end{array}$ \\
\hline $\begin{array}{l}\text { To jump from the unstable and elevated base to the stable base } \\
\text { and from the stable base to the unstable and elevated base ** }\end{array}$ & $\begin{array}{c}\text { Vestibular } \\
\text { Somatosensory }\end{array}$ & $\begin{array}{l}\text { Repeat } 3 \text { times (exit and return } \\
\text { to trampoline) }\end{array}$ & $\begin{array}{c}\text { Trampoline } \\
\text { (jump) }\end{array}$ \\
\hline $\begin{array}{l}\text { On the unstable base, follow with the eyes (head remains } \\
\text { immobile) the movement of a moving point on the wall (laser) in } \\
\text { the } 8 \text { inverted (horizontal) position in the clockwise direction. ** }\end{array}$ & $\begin{array}{l}\text { Somatosensory } \\
\text { Visual }\end{array}$ & 3 repetitions & Laser \\
\hline $\begin{array}{l}\text { On the unstable base, follow with the eyes (the head remains } \\
\text { immobile) the movement of a moving point on the wall (laser) } \\
\text { in the } 8 \text { inverted (horizontal) position in a counterclockwise } \\
\text { direction. ** }\end{array}$ & $\begin{array}{l}\text { Somatosensory } \\
\text { Visual }\end{array}$ & 3 repetitions & Laser \\
\hline Play: jump rope & $\begin{array}{l}\text { Reinforce trained movements } \\
\text { and postures }\end{array}$ & Free time & Rope \\
\hline \multicolumn{4}{|c|}{ DAY 13} \\
\hline Activity & Focus & Time/repetition & Material \\
\hline $\begin{array}{l}\text { To stand with the right foot on an unstable and elevated base } \\
\text { with open eyes looking at a fixed point on the wall. ** }\end{array}$ & $\begin{array}{c}\text { Vestibular } \\
\text { Somatosensory } \\
\text { Visual }\end{array}$ & $\begin{array}{l}1 \text { minute } \\
\text { Repeat } 3 \text { times }\end{array}$ & $\begin{array}{l}\text { Trampoline } \\
\text { (jump) }\end{array}$ \\
\hline $\begin{array}{l}\text { To stand with the right foot on an unstable and elevated base } \\
\text { with open eyes looking at a fixed point on the wall. ** }\end{array}$ & $\begin{array}{c}\text { Vestibular } \\
\text { Somatosensory } \\
\text { Visual }\end{array}$ & $\begin{array}{l}1 \text { minute } \\
\text { Repeat } 3 \text { times }\end{array}$ & $\begin{array}{l}\text { Trampoline } \\
\text { (jump) }\end{array}$ \\
\hline $\begin{array}{l}\text { To jump from the unstable and elevated base to the stable base } \\
\text { and from the stable base to the unstable and elevated base ** }\end{array}$ & $\begin{array}{c}\text { Vestibular } \\
\text { Somatosensory }\end{array}$ & $\begin{array}{l}\text { Repeat } 3 \text { times (exit and return } \\
\text { to trampoline) }\end{array}$ & $\begin{array}{c}\text { Trampoline } \\
\text { (jump) }\end{array}$ \\
\hline $\begin{array}{l}\text { On the unstable base, follow with the eyes (the head remains } \\
\text { immobile) the movement of a moving point on the wall (laser) } \\
\text { in the } 8 \text { inverted (horizontal) position in a counterclockwise } \\
\text { direction. ** }\end{array}$ & $\begin{array}{l}\text { Somatosensory } \\
\text { Visual }\end{array}$ & 3 repetitions & Laser \\
\hline $\begin{array}{l}\text { On the unstable base, follow with the eyes (head remains } \\
\text { immobile) the movement of a moving point on the wall (laser) } \\
\text { in the } 8 \text { inverted (horizontal) position in the clockwise } \\
\text { direction. ** }\end{array}$ & $\begin{array}{l}\text { Somatosensory } \\
\text { Visual }\end{array}$ & 3 repetitions & Laser \\
\hline Play: Miniature soccer game & $\begin{array}{l}\text { Reinforce trained movements } \\
\text { and postures }\end{array}$ & 5 kicks for each schoolchild & Miniature soccer game \\
\hline \multicolumn{4}{|c|}{ DIA 14} \\
\hline Activity & Focus & Time/repetition & Material \\
\hline $\begin{array}{l}\text { On an unstable and elevated base keep your eyes fixed on an } \\
\text { object (ball) and turn your head in the direction of NO. ** }\end{array}$ & $\begin{array}{c}\text { Vestibular } \\
\text { Somatosensory } \\
\text { Visual }\end{array}$ & $\begin{array}{l}\text { Repeat } 3 \text { complete round-trip } \\
\text { times }\end{array}$ & $\begin{array}{l}\text { Toy bowling ball (black) } \\
\text { Trampoline }\end{array}$ \\
\hline $\begin{array}{l}\text { On an unstable and elevated base keep your eyes fixed on an } \\
\text { object (ball) and turn your head in the direction of YES. ** }\end{array}$ & $\begin{array}{c}\text { Vestibular } \\
\text { Somatosensory } \\
\text { Visual } \\
\end{array}$ & $\begin{array}{l}\text { Repeat } 3 \text { complete round-trip } \\
\text { times }\end{array}$ & $\begin{array}{l}\text { Toy bowling ball (black) } \\
\text { Trampoline }\end{array}$ \\
\hline $\begin{array}{l}\text { On an unstable and elevated base, follow the movement of a } \\
\text { moving point (laser) on the wall in the horizontal direction. }\end{array}$ & $\begin{array}{c}\text { Vestibular } \\
\text { Somatosensory } \\
\text { Visual }\end{array}$ & $\begin{array}{l}\text { Repeat } 3 \text { complete round-trip } \\
\text { times }\end{array}$ & Laser \\
\hline $\begin{array}{l}\text { On an unstable and elevated base, follow the movement of a } \\
\text { moving point (laser) on the wall in the vertical direction. }\end{array}$ & $\begin{array}{l}\text { Vestibular } \\
\text { Somatosensory } \\
\text { Visual }\end{array}$ & $\begin{array}{l}\text { Repeat } 3 \text { complete round-trip } \\
\text { times }\end{array}$ & Laser \\
\hline To jump on one foot on an unstable and elevated base. & $\begin{array}{c}\text { Vestibular } \\
\text { Somatosensory }\end{array}$ & Free jump & Laser \\
\hline Play: Miniature soccer game & $\begin{array}{l}\text { Reinforce trained movements } \\
\text { and postures } \\
\end{array}$ & 5 kicks for each schoolchild & Miniature soccer game \\
\hline \multicolumn{4}{|c|}{$\begin{array}{l}\text { * Exercises performed individually. Other students in the group wait. } \\
\star \star \text { Activity performed individually and barefeet. }\end{array}$} \\
\hline \multicolumn{4}{|l|}{$\begin{array}{l}\text { Stable base: floor } \\
\text { Stable and high base: bench } \\
\text { Unstable base: silicone cushion } \\
\text { Unstable and elevated base: trampoline }\end{array}$} \\
\hline
\end{tabular}


As explained in Chart 2, the three systems of body balance were contemplated, namely: visual, somatosensory and vestibular. These systems were worked on in some activities in isolation and in others simultaneously. In addition to the directed activities, games were proposed to resume the movements or skills stimulated in the directed activity. The directed exercises were progressively increasing the difficulty.

The Cawthorne and Cooksey protocol was adopted as the basis for eye and body movements. However, striving to include the proprioceptive system in the training program, activities were included with some sensory integration strategies (such as staying with and without shoes, on a stable or unstable basis, etc.). The main focus (BB system) was indicated in each activity.

The total number of sessions of the studies shown in Chart 1 was 287 sessions, which divided by the studies that made this specification (23), an average of 16.87 sessions was obtained. For the present program, 14 training sessions were proposed.

It was found the use of repetitions in numbers and in time (isolated or simultaneously) in the selected studies, with values between three and 10 repetitions, and the repetition time between one and three minutes. Therefore, seeking to establish values similar to these, the present program proposes counting the numbers of the exercises (between three and five) and staying between 10 seconds and 1 minute in each exercise.

Among the studies with children's samples that pointed out the duration of each session in their methodologies (Chart 1), there were times between 20 and 60 minutes. Making the average among all, the value of 41 minutes was obtained. For the present program, a 30-minute session was proposed.

The results showed that most of the studies presented in Chart 1 (67.85\%) proposed therapeutic programs organized in weeks, and thus the present program was also organized. The average number of weeks foreseen by these studies was calculated, checking the value of eight weeks. Therefore, the present study organized the body balance training program in seven weeks, staying one week (closing eight) as a technical reserve for possible session recovery.

There was a recurrence of studies addressing the VR in Brazil, given the high percentage of Brazilian studies $^{6,7,14-28}$ on the subject. However, this context seems to be restricted to universities, still in the field of research, because in a systematic review ${ }^{29}$ on the effectiveness of vestibular rehabilitation in Primary Health
Care, no Brazilian studies were identified, indicating that in Brazil the VR seems to still be restricted to academy.

There was a wide use of the Cawthorne and Cooksey protocol ${ }^{6,7,15-18,21-28}$, which possibly stems from the fact that this protocol restores dynamic balance and spatial orientation, covering both eye movements and head movements in several directions. In addition, it stimulates the movements of the limbs and trunk to train dynamic balance ${ }^{16}$.

In general, the protocols and strategies selected by the studies in Chart 1 primarily stimulated one or another of the pillars of the vestibular system. The vestibular and visual systems are primarily stimulated in the Cawthorne and Cooksey protocol, with an emphasis on eye, head and trunk movement ${ }^{16}$, and by virtual reality strategies ${ }^{19}$. The somatosensory system is privileged in the sensory integration strategy ${ }^{26}$. Again, this seems to be linked to the fact that existing and published studies were restricted to research, when only one element is focused, seeking to understand the impact of this element on the others.

Concerning the age of the participants, there was no uniformity in the classifications of the age groups, with the age of 16, being considered "child" 22 and "adult" Likewise, some studies consider age over 60 to be "adult"19-22,27,31, while others consider the age of 60 as the lower limit to consider the "elderly" subject ${ }^{23-25}$.

The body balance system, whose development occurs throughout life, has peculiarities in each phase, which are relevant and must be considered. For example, changes in BB predispose the elderly to fall, while for the child, the vestibular system represents a regulator and mediator for new motor learning ${ }^{32}$. Adopting a consolidated classification, such as that provided for by child and adolescent statute (Law \# $8069 / 1990)^{32}$ can prevent research bias, attributing greater reliability.

Another highlight is that from the union of the selected studies (Chart 1) with the participation of adults and the elderly, many with overlapping ages (similar ages), it was found that $67.76 \%$ of the selected studies deal with this audience. This confirms that the occurrence of complaints and otoneurological symptoms prevails among the older age groups ${ }^{33}$, while the child audience, despite presenting similar symptoms, they present difficulties in identifying and expressing them ${ }^{34}$.

According to the Orientation Guide on the performance of the speech therapist in the assessment and rehabilitation of body balance ${ }^{35}$, the treatment time is variable and will depend on the otoneurological picture, 
existence of comorbidities, age and the period in which the therapeutic intervention was started. The analysis of the studies in Chart 1 seems to strengthen this position, since there was considerable variability in the duration of the programs presented.

In the BB training program proposed in Chart 2, guided and playful activities were developed, as indicated by some authors ${ }^{11}$, the first of which progressively increased the degree of difficulty, 12-14.

The present program is dedicated to application especially for children, who, according to the Child and Adolescent Statute ${ }^{32}$, are individuals up to 12 years old. However, activities require a certain motor and cognitive demand, in addition to the child's active participation, and are not suitable for children under four years old ${ }^{11}$.

As in other studies ${ }^{36-38}$, a program was proposed using the combination of strategies in both directed activities. However, only in this study, all BB systems were stimulated, giving this program an unprecedented character of integral intervention.

\section{CONCLUSION}

From the variables in this integrative review, especially regarding the protocol or strategy used for the rehabilitation of the vestibular function, no study was found proposing the stimulation of the three BB systems, and those found emphasized one or two of these systems, depending on the study. Still, the lack of standardization found in the analyzed variables, indicated that there is no uniformity regarding the rehabilitation of vestibular function in children, adults and the elderly.

In the present study, a body balance training program was developed, whose domains were adopted based on the integrative review, highlighting the fact that the application of this program in full, guarantees the stimulation of the three systems that make up the BB. Considering the lack of programs for rehabilitation of vestibular function for children, it is estimated that this study has contributed to expand the possibilities in this area.

As a suggestion for future studies, it is considered that the application of this program to the child audience represents an important step towards speech rehabilitation and related areas.

\section{REFERENCES}

1. Maia FCZ, Portinho F. Princípios anatomofisiológicos que regem o equilíbrio. In: Maia FCZ, Albernaz PLM, Carmona S, editors. Otoneurologia Atual. Rio de Janeiro: Revinter; 2014. p. 1-23.

2. Ganança MM, Munhoz MS, Caovilla HH, Silva MLG. Introdução: conceitos em otoneurologia. In: Ganança MM, Munhoz MS, Caovilla HH, Silva MLG, editors. Otoneurologia ilustrada. São Paulo: Editora Atheneu, 2005. p.1-17.

3. Pereira $A B$, Silva GSM, Assunção ARM, Atherino ACCT, Volpe FM, Felipe L. Cervical vestibular evoked myogenic potentials in children. Braz. J. Otorhinolaryngol. 2015;81(4):358-62.

4. Perez MLD, Lemos NFD, Aprile MR, BrancoBarreiro FCA. Otoneurological symptoms in school-aged children. Revista Equilíbrio Corporal Saúde. 2014;6(2):48-53.

5. Ganança MM, Munhoz MS, Caovilla HH, Silva MLG. Como lidar com as tonturas e sintomas associados. In: Ganança, MM, Caovilla HH, editors. Estratégias terapêuticas em otoneurologia. São Paulo: Editora Atheneu, 2000. p.1-20.

6. Bittar RSM, Pedalini MEB, Medeiros IRT, Bottino MA, Bento RF. Reabilitação vestibular na criança: estudo preliminar. Rev. Bras. Otorrinolaringol. 2002;68(4):496-9.

7. Medeiros IRT, Bittar RSM, Pedalini MEB, Lorenzi MC, Kii MA, Formigoni LG. Avaliação do tratamento dos distúrbios vestibulares na criança através da posturografia dinâmica computadorizada: resultados preliminares. J. Pediatr. 2003;79(4):337-42.

8. Leong DF, Master CL, Messner LV, Pang Y, Smith C, Starling AJ. The effect of saccadic training on early reading fluency. Clin. Pediatr. 2014;53(9):858-64.

9. Goulème N, Gérard CL, Bucci MP. The effect of training on postural control in dyslexic children. PloS One. 2015;10(7):e0130196.

10. Fong SSM, Guo X, Liu KP, Ki WY, Louie LH, Chung $\mathrm{RC}$ et al. Task-specific balance training improves the sensory organisation of balance control in children with developmental coordination disorder: a randomised controlled trial. Sci. Rep. 2016;6(20945):1-8. 
11. Lofti Y, Rezazadeh N, Moossavi A, Haghgoo HA, Moghadam SF, Pishyareh $E$ et al. Introduction of pediatric balance therapy in children with vestibular dysfunction: review of indications, mechanisms, and key Exercises. Iran. Rehabil. J. 2016;14(1):5-14.

12. Jafarlou F, Jarollahi F, Ahadl M, SadeghiFiroozabadi V, Haghani H. Oculomotor rehabilitation in children with dyslexia. Med. J. Islam. Repub. Iran. 2017;31(125):1-9.

13. Ebrahimi $A A$, Jamishidi $A A$, Movallari $G$, Rahgozar $M$, Haghgoo HA. The effect of Vestibular Rehabilitation Therapy Program on sensory organization of deaf children with bilateral vestibular dysfunction. Acta Med. Iran. 2017;55(11):683-9.

14. Garcia AP, Ganança MM, Cusin FS, Tomaz A, Ganança FF, Caovilla HH. Vestibular rehabilitation with virtual reality in Ménière's disease. Braz. J. Otorhinolaryngol. 2013;79(3):366-74.

15. Longo IA, Nunes ADM, Rocha $\mathrm{CH}$, Branco FM, Moreira RR, Neves-Lobo IF et al. Effects of a vestibular rehabilitation program on workers in the working environment: a pilot. Rev. CEFAC. 2018;20(3):304-12.

16. Macedo LB. Análise da eficácia da reabilitação vestibular em indivíduos idosos com queixa de tontura [course completion work]. Porto Alegre (RS): Universidade Federal do Rio Grande do Sul, Especialização em Audiologia; 2014.

17. Manso A, Ganança MM, Caovilla EH. Vestibular rehabilitation with visual stimuli in peripheral vestibular disorders. Braz. J. Otorhinolaryngol. 2016;82(2):232-41.

18. Mantello RB, Morigutti JC, Rodrigues-Junior AL, Ferrioli E. Vestibular rehabilitation's effect over the quality of life of geriatric patients with labyrinth disease. Rev. Bras. Otorrinolaringol. 2008;74(2):172-80.

19. Martini APR. Treino de equilíbrio e marcha em indivíduos hemiplégicos por acidente vascular cerebral utilizando realidade virtual [course work completion]. Santa Maria (RS): Universidade Federal de Santa Maria; 2012.

20. Morezetti PG, Ganança CF, Chiari BM. Comparação de diferentes protocolos de reabilitação vestibular em pacientes com disfunções vestibulares periféricas. J. Soc. Bras. Fonoaudiol. $2011 ; 23(1): 44-50$.
21. Nishino LK, Ganança CF, Manso A, Campos CAH, Korn GP. Personalized vestibular rehabilitation: medical chart survey with patients seen at the ambulatory of otoneurology of I.S.C.M.S.P. Rev. Bras. Otorrinolaringol. 2005;71(4):440-7.

22. Patatas OHG, Ganança CF, Ganança FF. Quality of life of individuals submitted to vestibular rehabilitation. Braz. J. Otorhinolaryngol. 2009;75(3):387-94.

23. Ribeiro ASB, Pereira JS. Melhora do equilíbrio e redução da possibilidade de queda em idosas após os exercícios de Cawthorne e Cooksey. Rev. Bras. Otorrinolaringol. 2005;71(1):38-46.

24. Ricci NA. Efeitos da reabilitação vestibular no equilíbrio corporal de idosos vestibulopatas crônicos: ensaio clínico randomizado [Dissertation]. São Paulo (SP): Universidade Federal de São Paulo; 2013.

25. Rocha Junior PR, Kozan ES, Moraes JF, Pereira FG, Moreno AB. Reabilitação vestibular na qualidade de vida e sintomatologia de tontura de idosos. Ciênc. Saúde Colet. 2014;19(8):3365-74.

26. Rogatto ARD, Pedroso L, Almeida SEM, Oberg TD. Proposta de um protocolo para reabilitação vestibular em vestibulopatias periféricas. Fisioter. Mov. 2010;23(1):83-91.

27. Tsukasmoto HF, Costa VSP, Silva Junior RA, Pelosi GG, Marchiori LLM, Vaz CRS et al. Effectiveness of a Vestibular Rehabilitation Protocol to improve the health-related quality of life and postural balance in patients with vertigo. Int. Arch. Otorhinolaryngol. 2015;19(3):238-47.

28. Zanardini $F H$, Zeigelboim BS, Jurkiewicz AL, Marques JM, Martins-Basseto J. Reabilitação vestibular em idosos com tontura. Pró-Fono $\mathrm{R}$ Atual. Cientif. 2007;19(2):177-84.

29. Lopes AA, Lemos SMA, Chagas CA, Araújo SG, Santos JN. Scientific evidence of vestibular rehabilitation in primary health care: a systematic review. Audiol., Commun. Res. 2018;23:e2032.

30. McCoy SW, Jirikowic T, Price R, Ciol MA, Hsu LY, Dellon B et al. Virtual Sensorimotor Balance Training for children with fetal alcohol spectrum disorders: feasibility study. Phys Ther. 2015;95(11):1569-81.

31. Mirelman A, Herman T, Nicolai S, Zijlstra A, Zijlstra W, Becker $C$ et al. Audio-Biofeedback Training for posture and balance in patients with Parkinson's disease. J. Neuroengineering Rehabil. 2011;8(35):1-7. 
32. BRAZIL. Law 8,069, of July 13, 1990. Provides for the Statute of Children and Adolescents and provides other measures. Official Gazette of the Federative Republic of Brazil, Brasília, DF, 16 jul. 1990. Available at: http://www.planalto.gov.br/ ccivil_03/leis//8069.htm

33. Caovilla HH, Ganança CF, Ganança MM. Avaliação do equilíbrio corporal. Conceituação e aplicação clínica. In: Boéchat EM, Menezes PL, Couto CM, Frizzo ACF, Scharlach RC, Anastacio ART, editors. Tratado de Audiologia. Rio de Janeiro: Guanabara Koogan, 2015. p.300-9.

34. Bohlsen YA, Martins MC. Avaliação vestibular da criança. In: Boéchat EM, Menezes PL, Couto CM, Frizzo ACF, Scharlach RC, Anastacio ART, editors. Tratado de Audiologia: Rio de Janeiro: Guanabara Koogan, 2015. p.551-9.

35. Sistema de Conselhos de Fonoaudiologia. Guia de Orientação - Atuação do Fonoaudiólogo em avaliação e reabilitação da função vestibular. 2017.

36. Alahamari KA, Sparto PJ, Marchetti GF, Redfern MS, Furman JM, Whitney S. Comparison of Virtual Reality Based Therapy with Customized Vestibular Physical Therapy for the treatment of vestibular disorders. IEEE Trans. Neural Syst. Rehabil. Eng. 2014;22(2):389-99.

37. Marioni G, Fermo S, Lionello M, Fasanaro E, Giacomelli L, Zanon S et al. Vestibular rehabilitation in elderly patients with central vestibular dysfunction: a prospective, randomized pilot study. Age Ageing. 2013;35(6):2315-27.

38. Ozgen G, Karapolat H, Akkoc Y, Yuceyar N. Is customized vestibular rehabilitation effective in patients with multiple sclerosis? A randomized controlled trial. Eur. J. Phys. Rehabil. Med. 2016;52(4):466-78. 